\title{
PERUBAHAN SOSIAL KAUM PEREMPUAN SAMIN DI DESA KLOPODUWUR KECAMATAN BANJAREJO KABUPATEN BLORA TAHUN 1995-2012
}

\author{
Irma Septikawati \& Novi Triana Habsari*
}

\begin{abstract}
Abstrak
Penelitian ini bertujuan untuk mengetahui Bentuk Perubahan Sosial Kaum Perempuan Samin Di Desa Klopoduwur Kecamatan Banjarejo Kabupaten Blora Tahun 1995-2012.. Adapun bentuk dari penelitian ini adalah penelitian kualitatif datanya tidak berbentuk angka, menekankan pada kondisi obyek yang alamiah untuk memahami dan menafsirkan makna suatu peristiwa, kenyataannya tidak ada rekayasa dalam aktifitas tersebut saat penelitian berlangsung. Pengambilan data melalui sumber data primer diperoleh dari wawancara dengan informan, dan sumber data sekunder diperoleh dari Desa Klopoduwur dan profil sejarah Samin serta bahan pustaka. Validasi yang digunakan yaitu validasi sumber dan teknik. Analisis data yang digunakan adalah analisis data model interaktif Miles dan Huberman.

Berdasarkan hasil penelitian dapat diketahui bentuk perubahan kaum perempuan Samin meliputi perubahan secara cepat yakni pemanfaatan teknologi yang memberi efek pada perempuan Samin, dan perubahan lambat berupa pola perilaku yang membutuhkan penyesuaian lebih lama seperti peralihan cara berpakaian dari kebaya ke pakaian modern. Perubahan yang direncanakan seperti pernikahan dengan mencatatkan ke KUA, pendidikan ada kemauan bersekolah serta ada kesediaan patuh terhadap pemerintah. Perubahan tidak direncanakan yakni mereka tidak memiliki lahan pertanian (akibat ketidaksadaran) dalam persoalan ekonomi sekitar tahun 1997. Faktor yang berpengaruh dalam perubahan yakni intern meliputi keterbukaan dengan masyarakat, adanya penduduk baru, dan ketidakpuasan pada pola hidup yang lama. Faktor ekstern meliputi mata pencaharian di bidang pertanian, sistem kepercayaan, media masa dalam penambahan informasi baru. Dampak perubahan yang dialami oleh kaum perempuan Samin antara lain 1).kehidupan kaum perempuan Samin dulunya tradisional, mulai mengalami kemajuan akibat arus globalisasi berupa kemajuan teknologi yang telah memasuki ranah keseharian mereka. 2). Ekonomi perempuan Samin dulunya kekurangan sekarang kondisi baik, 3).Perubahan dalam diri perempuan Samin, dapat menyamakan derajat dengan masyarakat sekitar.
\end{abstract}

\section{Kata Kunci : Perubahan Sosial, Kaum Perempuan, Samin}

\section{Pendahuluan}

Pada dasarnya kehidupan masyarakat saat ini sudah mengalami perubahan secara dinamis. Hal ini menunjukan bahwa pola masyarakatnya masih menginginkan suatu bentuk kehidupan yang mengarah lebih modern. Terbukti dengan mengalami pergeseran nilai sosial, perilaku, susunan organisasi, lembaga sosial, stratifikasi sosial, kekuasaan, wewenang, dan sebagainya (Syahrial Syarbaini Dan Rusdiyanta, 2009: 135). Perubahan yang terjadi dalam masyarakat tidak terlepas dari pengaruh perkembangan ilmu pengetahuan dan teknologi yang semakin luas. Hal yang demikian tersebut merupakan suatu makna perubahan dalam masyarakat, yang bergerak dari keadaan tradisional atau pra modern menuju masyarakat yang modern 
(Abdulsyani, 2012: 173). Berkaitan dengan hal tersebut perubahan tradisional menuju masa pasca tradisional tentu akan mengakibatkan masyarakat untuk tetap berpandangan lebih rasional. Pada dasarnya bentuk perubahan sosial itu terarah (directed change) yang didasarkan pada (planning) perencanaan (Soerjono Soekanto, 2010: 304). Melihat pernyataan tersebut tentu akan berdampak pada pola perubahan yang terlihat, khususnya pada kaum perempuan. Perempuan yang dulunya identik dengan mendidik anak, merawat kebersihan dan keindahan rumah tangga, atau urusan domestik, seperti memasak, mencuci dan merawat anak dianggap kodrat perempuan (Dwi Narwoko dan Bagong Suyanto, 2010: 340).

Perubahan tersebut sebenarnya belum terlihat pada masyarakat Samin secara keseluruhan. Hal ini disebabkan pemikiran dari masyarakat Samin masih cenderung pada sikap hidup yang masih tradisional. Sikap seperti ini disebabkan pada pola pikir masyarakat Samin yang masih tertutup dan belum adanya interaksi dengan masyarakat luar. Keberadaan pola ajaran yang dilaksanakan sesuai dengan prinsip ajaran dari Samin Surosentiko yang dijadikan pedoman bersikap dan bertingkah laku yang baik dan jujur khususnya masyarakat Samin (Titi Mumfangati, 2007: 30). Kaum perempuan Samin dan keturunannya telah berusaha untuk mempertahankan identitas dirinya sebagai pengikut Samin. Identitas tersebut seperti halnya bahasa, pakaian, adat istiadat maupun kebiasaan-kebiasaan dari masyarakat Samin (Titi Mumfangati, 2007:43). Kaum perempuan Samin dari tahun ke tahun sudah mengalami perubahan. Perubahan itu muncul sebab adanya faktor intern, dimana keberadaan faktor ini terjadi pada perubahan dari dalam diri sendiri (personal) maupun lingkungan kelompok itu. Hal ini dapat diartikan bahwa keberadaan faktor intern mencakup pada adanya sikap mau membuka diri, dan mau menerima kebudayaan dari luar kelompok itu sendiri yang secara tidak langsung akan mempengaruhi perubahan sosial kaum perempuan Samin (Andrik Purwasito, 2003: 82). Pada satu sisi, selain dari faktor intern, juga tidak menutup kemungkinan ada faktor dari luar yang dapat mempengaruhi pola perubahan kaum perempuan Samin. Faktorfaktor itu misalnya sering terjadi kontak dengan budaya lain sehingga akan memberi dampak pada kebiasaan dari kelompok kaum perempuan Samin itu sendiri. Kekuatan jati diri mereka tentu akan tetap bertahan sesuai dengan komunitasnya. Sehubungan dengan hal tersebut, maka perubahan sosial yang dialami kaum perempuan Samin ini menarik untuk diteliti

\section{Tujuan dan Manfaat Penelitian}

Adapun tujuan dari penelitian ini adalah sebagai berikut: 
1. Untuk mengetahui bentuk-bentuk perubahan sosial kaum perempuan Samin di Desa Klopoduwur Kecamatan Banjarejo Kabupaten Blora tahun 19952012.

2. Untuk mengetahui faktor-faktor yang mempengaruhi perubahan sosial kaum perempuan Samin di Desa Klopoduwur Kecamatan Banjarejo Kabupaten Blora tahun 1995-2012.

3. Untuk mengetahui dampak perubahan sosial bagi kehidupan kaum perempuan Samin di Desa Klopoduwur Kecamatan Banjarejo Kabupaten Blora tahun 19952012.

Penelitian ini diharapkan dapat bermanfaat oleh berbagai pihak diantaranya:

1. Bagi Program Studi Pendidikan Sejarah IKIP PGRI MADIUN

Penelitian ini dapat menambah koleksi di laboratorium Program studi Pendidikan Sejarah IKIP PGRI MADIUN khususnya dalam bahan kajian sejarah lokal. 2. Bagi Masyarakat di Desa Klopoduwur

Hasil penelitian ini berguna untuk menambah informasi dalam studi masyarakat berkaitan dengan perubahan sosial kaum perempuan Samin serta tidak lagi mengucilkan para kaum perempuan Samin.

\section{Bagi Pemerintah Kabupaten Blora}

Penelitian ini diharapkan dapat memberikan gambaran dan bahan pertimbangan dalam rangka membuat kebijakan untuk mengatasi kehidupan masyarakat yang masih tertinggal.

\section{Tinjauan Pustaka}

\section{A. Perubahan Sosial}

\section{Pengertian Perubahan Sosial}

Dany Haryanto dan Edwi Nugroho (2011: 237) menerjemahkan perubahan sosial sebagai segala perubahan pada lembaga-lembaga sosial dalam suatu masyarakat mempengaruhi sistem-sistem sosial, termasuk nilai-nilai, pola-pola perilaku ataupun sikap-sikap dalam masyarakat itu yang terdiri dari berbagai kelompok sosial. Perubahan sosial juga dapat diartikan sebagai proses sosial yang dialami oleh anggota masyarakat serta semua unsur-unsur budaya dan sistemsistem sosial, dimana semua tingkatan kehidupan masyarakat secara sukarela atau dipengaruhi oleh unsur-unsur eksternal meninggalkan pola kehidupan, budaya, dan sistem lama kemudian menyesuaikan diri atau menggunakan pola-pola kehidupan, budaya, dan sistem sosial yang baru (Burhan Bungin, 2009: 91). Pendapat yang lain juga dikemukakan oleh Farley (dalam Sztompka, 2008: 5) bahwa perubahaan sosial merupakan perubahan pola perilaku, hubungan sosial, lembaga dan struktur sosial pada waktu tertentu.

Dari beberapa pemaparan ahli tersebut di atas, secara umum dapat dijelaskan, bahwa perubahan sosial diartikan sebagai segala perubahan yang 
terjadi pada struktur dan fungsi suatu sistem sosial yang dapat mempengaruhi nilai-nilai, sikap-sikap dan pola perilaku diantara kelompok dalam suatu masyarakat dan di dalamnya akan ada proses transformasi yang cukup beragam melalui saluran dari luar baik budaya ataupun pola kehidupanya. Di samping itu, terjadinya proses perubahan tersebut juga akan dibarengi dengan penemuan-penemuan baru (difusi) sehingga akan mengubah pola sistem sosial yang ada di masyarakat.

\section{Faktor-Faktor yang Mempengaruhi Perubahan Sosial}

Di dalam perubahan sosial tentu ada faktor-faktor yang mendorong terjadinya suatu perubahan dalam masyarakat seperti yang diutarakan Soerjono Soekanto (2010: 275-282) yaitu sebagai berikut:

a. Faktor dari dalam (intern)

1) Bertambah atau berkurangnya penduduk

Bertambahnya jumlah penduduk yang sangat cepat ... akan menyebabkan terjadinya perubahan dalam struktur masyarakat, terutama lembagalembaga kemasyarakatan. Hal ini disebakan semakin banyaknya jumlah penduduk akan mengakibatkan semakin luasnya variasi pola pikir maupun gaya hidup yang baru.

2) Penemuan-penemuan baru

Penemuan-penemuan baru akan menyebabkan proses terjadinya perubahan-perubahan sosial.
Penemuan baru tersebut dapat dibedakan menjadi dua, yakni discovery dan invention.

3) Pertentangan (Conflict) masyarakat

Pertentangan atau konflik di dalam masyarakat dapat terjadi baik antara individu dengan kelompok maupun perantara kelompok dengan kelompok. Hal ini biasanya ada proses berseberangan pendapat, ideologi, maupun yang lainnya.

b. Faktor dari Luar (ekstern) masyarakat

1) Bencana alam atau kondisi lingkungan fisik

Terjadinya bencana alam seperti gempa bumi, angin topan, banjir besar, dan lain-lain dimungkinkan akan menyebabkan masyarakat yang mendiami daerah-daerah tersebut terpaksa harus meninggalkan tempat tinggalnya. Masyarakat harus mampu beradaptasi dengan kondisi lingkungan yang baru dan dapat mengakibatkan perubahan pada lembaga kemasyarakatannya.

2) Peperangan

Peperangan dengan negara lain dapat pula menyebabkan terjadinya perubahan-perubahan sosial, sebab biasanya negara yang menang akan memaksakan kebudayaanya pada negara yang kalah. Selanjutnya, secara otomatis tentu pihak yang menang akan menguasai daerah dari pihak yang kalah dan akan menuntut pihak yang 
kalah untuk tunduk pada setiap peraturan pihak yang menang.

3) Pengaruh kebudayaan masyarakat lain Apabila sebab perubahan bersumber pada masyarakat lain, mungkin terjadi karena kebudayaan dari masyarakat lain melancarkan pengaruhnya pada masyarakat yang terkena dampak dari perubahan itu sendiri. Hal ini dipengaruhi adanya pola interaksi antara masyarakat yang satu ke masyarakat yang lainnya, dan sudah barang tentu dapat mempengaruhi kebudayaan tersebut.

. Dari pemaparan tersebut, dapat disimpulkan terjadinya perubahan sosial dipengaruhi oleh faktor intern yang berasal dari dalam masyarakat itu sendiri seperti bertambah dan berkurangnya jumlah penduduk, penemuan baru berupa teknologi, dan pertentangan atau konflik yang terjadi dalam masyarakat. Selain itu, juga dipengaruhi oleh faktor ekstern yang berasal dari luar masyarakat. Misalnya, bencana alam, peperangan dan pengaruh dari kebudayaan lain.

\section{Bentuk-Bentuk Perubahan Sosial}

Beberapa bentuk-bentuk perubahan sosial itu seperti yang dikemukakan oleh Soerjono Soekanto, 2010: 269-273 sebagai berikut:

a. Perubahan Lambat dan Perubahan Cepat

Perubahan yang memerlukan waktu lama dan rentetan-rentetan perubahan kecil yang saling mengikuti dengan lambat dinamakan evolusi. Sebaliknya, perubahan cepat atau revolusi adalah perubahan yang terjadi secara cepat mengenai lembaga-lembaga kemasyarakatan dan dapat direncanakan terlebih dahulu atau tanpa rencana.

b. Perubahan Kecil dan Perubahan Besar

Perubahan kecil adalah perubahanperubahan yang terjadi pada unsurunsur struktur sosial yang tidak membawa pengaruh langsung atau berarti bagi masyarakat. Misalnya perubahan model pakaian, tidak akan membawa pengaruh bagi masyarakat secara keseluruhan. perubahan besar merupakan perubahan yang akan membawa pengaruh besar pada masyarakat dan dapat mempengaruhi lembaga kemasyarakatan yang bersangkutan.

c. Perubahan yang Dikehendaki (Perubahan yang Direncanakan) dan Perubahan yang Tidak Dikehendaki (Perubahan yang Tidak Direncanakan

Perubahan yang dikehendaki atau direncanakan merupakan perubahan yang diperkirakan atau yang direncanakan terlebih dahulu oleh pihakpihak yang hendak mengadakan perubahan di dalam masyarakat. perubahan sosial yang tidak dikehendaki atau yang tidak direncanakan merupakan perubahan-perubahan yang terjadi tanpa dikehendaki, berlangsung di luar 
jangkauan pengawasan masyarakat dan dapat menyebabkan timbulnya akibatakibat sosial yang tidak diharapkan masyarakat.

Selanjutnya, bentuk-bentuk perubahan sosial juga diutakan oleh Syahrial Syarbaini dan Rusdiyanta (2009: 138-140) yang meliputi:

a. Perubahan evolusi dan perubahan revolusi

Perubahan evolusi adalah perubahan sosial yang terjadi dalam proses yang lambat dan dalam waktu yang cukup lama tanpa ada kemauan tertentu dari masyarakat yang bersangkutan. Perubahan secara revolusi merupakan perubahan yang berlangsung secara cepat dan tidak ada kehendak atau perencanaan sebelumnya.

b. Perubahan yang direncanakan dan perubahan yang tidak direncanakan

Perubahan yang direncanakan adalah perubahan-perubahan terhadap lembaga-lembaga kemasyarakatan yang didasarkan pada perencanaan yang matang oleh pihak-pihak yang menghendaki perubahan tersebut. Pada satu sisi, perubahan sosial yang tidak direncanakan merupakan perubahan yang terjadi tanpa dikehendaki serta berlangsung di luar jangkauan pengawasan masyarakat dan dapat menyebabkan timbulnya dampakdampak dalam ranah sosial yang tidak diharapkan, seperti revolusi sosial yang terjadi dalam masyarakat

Selain itu, pendapat yang sama tentang bentuk-bentuk perubahan sosial juga disampaikan oleh Nanang Martono (2012: 13-15) bahwa pola tersebut dapat dijabarkan sebagai berikut:

a. Perubahan yang cepat (Revolusi) dan perubahan yang lambat (Evolusi)

Revolusi merupakan wujud perubahan sosial yang paling spektakuler dan sebagai tanda perpecahan mendasar dalam proses historis serta pembentukan masyarakat dari dalam. Satu sisi, perubahan evolusi dapat diartikan sebagai perubahan yang terjadi secara lambat dan memerlukan waktu cukup lama untuk mengalami perubahan.

b. Perubahan yang kecil dan perubahan yang besar

Perubahan yang kecil pada dasarnya merupakan perubahan yang terjadi pada struktur sosial yang tidak membawa pengaruh langsung bagi masyarakat, perubahan yang besar merupakan perubahan yang membawa pengaruh besar bagi masyarakat yang bersangkutan.

c. Perubahan yang dikehendaki (direncanakan) dan perubahan yang tidak dikehendaki (tidak direncanakan)

Perubahan yang direncanakan adalah perubahan yang direncanakan terlebih dahulu oleh pihak-pihak yang 
akan mengadakan perubahan, sedangkan perubahan yang tidak direncanakan merupakan perubahan yang terjadi tanpa direncanakan, berlangsung diluar jangkauan atau pengawasan masyarakat dan dapat menimbulkan akibat-akibat sosial yang tidak dikehendak.

Dari penjelasan diatas, dapat disimpulkan bahwa bentuk-bentuk perubahan sosial yang terjadi dalam masyarakat meliputi tiga bentuk yaitu: Pertama, Perubahan evolusi adalah perubahan yang terjadi sangat lambat dan membutuhkan waktu yang lama untuk mengalami perubahan, dan perubahan revolusi merupakan perubahan yang berlangsung sangat cepat dan dapat mempengaruhi lembaga kemasyarakatan. Kedua, Perubahan kecil tidak memiliki pengaruh yang berarti dalam kehidupan masyarakat, sebab terjadinya perubahan tersebut tidak akan mengakibatkan perubahan pada lembaga kemasyarakatan yang bersangkutan. perubahan besar dapat memberikan dampak yang cukup besar dalam kehidupan masyarakat tersebut. Hal ini disebabkan, perubahan itu akan mempengaruhi struktur sosial, nilai-nilai, norma-norma maupun kehidupan masyarakat secara luas. Ketiga, Perubahan yang dikehendaki merupakan perubahan yang direncanakan oleh pihak-pihak yang ingin adanya suatu perubahan dalam kehidupan masyarakat. perubahan yang tidak dikehendaki merupakan perubahan yang terjadi tanpa direncanakan terlihat dahulu, sehingga menimbulkan akibat sosial yang tidak diinginkan.

\section{B. Dinamika Kaum Perempuan Dalam Perspektif Sosial}

Secara etimologis, kata perempuan bernilai cukup tinggi, tidak dibawah, tetapi sejajar, bahkan lebih tinggi dari pada kata lelaki karena kata perempuan berasal dari kata empu yang berarti 'tuan', orang yang berkuasa', ataupun 'kepala', ataupun yang paling besar (Husain Haikal, 2012: 39). Meskipun makna dari kata perempuan itu lebih tinggi di bandingkan kata laki-laki, akan tetapi kenyataannya derajat perempuan dianggap lebih rendah karena menempatkan perempuan hanya sebagai the second sex, seperti yang tercermin dalam kebudayaan jawa dalam ungkapan proverbial yang sangat mengunggulkan lelaki sesuai dengan ungkapan "swarga nunut neraka katut", yang memiliki arti bahwa kebahagian atau penderitaan istri hanya tergantung pada suami, dimana perempuan dianggap tidak berperan dalam kehidupan (Fauzie Ridjal, Lusi Margiyani dan Agus Fahri Husein, 1993:50 ). Fungsi dan peran kaum perempuan zaman dulu hanya dianggap tidak berarti dan tidak memiliki peran apa-apa selain hanya menjadi alat kesenangan kaum laki-laki. Mereka tidak dipandang sebagai partner yang penuh di dalam rumah tangganya, apalagi sebagai istri kaum perempuan hanya sekedar 
menurut dan menuruti perintah suami (Hardjito Notopuro, 1984: 35). Peranan kaum perempuan hanya terbatas pada wilayah domestik. Khususnya pada tingkat keluarga dimana perempuan yang menjadi ibu harus bertanggung jawab mengasuh dan merawat anak-anaknya (Jajat Burhanudin dan Oman Fathurahman, 2004: 144). Memasuki tahun 1995 sampai 1999, kaum perempuan telah mengalami perubahan secara kontemporen dimulai pada saat modernisasi menjadi ideologi masyarakat (Irwan Abdullah, 2001: 5). Masuknya modernisasi memberikan dampak besar bagi perubahan kaum perempuan.

Perubahan tersebut terlihat pada terlibatan perempuan Di pasar kerja (sektor publik) tidak dapat dielakkan dalam proses modernisasi ... dan peluang itu dapat membantu kaum perempuan keluar dari kungkungan sektor domestik atau sektor tradisional (Nursyahbani Katjasungkana, 2001: 44). Selain itu faktor teknologi yang dapat mempengaruhi perubahan pada kaum perempuan. Kemajuan teknologi dipandang telah mengubah secara langsung kehidupan perempuan menjadi lebih baik (Judi Wajcman, Terjemahan Ima Susilowati, 2001: 66). Dampak secara langsung dapat terlihat pada mengalirnya berbagai informasi dari berbagai kemajuan teknologi baik dari media cetak, media elektronik bahkan media sosial sekalipun telah terinput pada pola hidup kaum perempuan. Selain itu, seiring berjalannya waktu, lambat laun pendidikan bagi perempuan juga mulai diterima oleh masyarakat (Tineke Hellwig, terjemahan Mien Joebhaar, 2007: 32). Perubahan kaum perempuan yang cukup signifikan terjadi sekitar tahun 1999 sampai 2012. Dimana pada waktu itu sudah adanya gerakan emansipasi wanita yang telah memproklamasikan kemerdekaan kaum wanita dalam masyarakat ini (Nancy Van Vuuren, terjemahan Lunandi, 1990: 117). Selain itu adanya transformasi penyamarataan gender juga telah terlihat atau nampak pada kehidupan kaum perempuan saat ini. Perubahan tersebut terlihat pada peran perempuan yang memiliki dua dunia yaitu dunia rumah tangga dan dunia pergaulan hidup diluar rumah tangga. Dunia rumah tangga menuntut perempuan sebagai seorang ibu dan istri untuk tidak meninggalkan fungsinya dirumah sebagai pendidik (Jajat Burhanudin dan Oman Fathurahman, 2004: 29). Dengan demikian, dapat disimpulkan bahwa kaum perempuan sudah mengalami perubahan fungsi dan perannya dalam kondisi saat ini.

Pergeseran peran perempuan dari peran domestik ke publik merupakan tanda penting dari perkembangan realitas sosial, ekonomi, dan politik perempuan (Irwan Abdullah, 2006: 22). Berkaitan dengan hal tersebut, peran perempuan dalam ranah domestik hanya akan menempatkan pada posisi berada dalam ruang lingkup kecil saja. Hal ini disebabkan, perempuan dalam 
kehidupannya masih belum memberikan pengaruh yang lebih besar terhadap bidang tertentu, baik secara aspek ekonomi, sosial maupun politiknya. Dinamika ini akan memberi pengaruh terhadap pergeseran kehidupan yang tadinya hanya berskala kecil (lingkungan sesama kelompok) beranjak ke ranah publik (secara mengglobal). Indikasi ini muncul dari perubahan peran kaum perempuan yang telah berani masuk dalam berbagai aspekaspek kemasyarakatan baik dari aspek perpolitikan, sosial ataupun bidang ekonomi. Artinya, peran tersebut memberikan sumbangsih khususnya bagi kaum perempuan itu sendiri, sebab mereka mampu mengadopsi, beradaptasi dan belajar terhadap pemikiran-pemikiran baru dari interaksinya secara luas.

\section{Metode Penelitian}

Penelitian ini dilaksanakan di Desa Klopoduwur Kecamatan Banjarejo Kabupaten Blora. Penelitian berlangsung selama enam bulan. Pengambilan data berupa sumber data primer diperoleh melalui wawancara dengan informan, dan sumber data sekunder diperoleh dari Desa Klopoduwur dan profil sejarah Samin serta bahan pustaka. Pengumpulan data dilakukan dengan teknik observasi pasif yakni peneliti ketika pengamatan tidak seluruhnya ikut dalam kegiatan pada obyek penelitian, wawacara dengan beberapa informan yakni Kepala desa, Kepala dusun, Kepala paguyuban Samin dan Beberapa perempuan Samin yang berusia lanjut serta keturunannya maupun sekarang. Dokumen yang digunakan yaitu arsip desa Klopoduwur dan foto. Validasi data diperoleh melalui trianggulasi sumber dan teknik. Teknik trianggulasi sumber menekankan proses pengecekan data dari berbagai sumber dengan membandingkan dari sumber satu dan lain namun dalam pokok permasalahan sama.

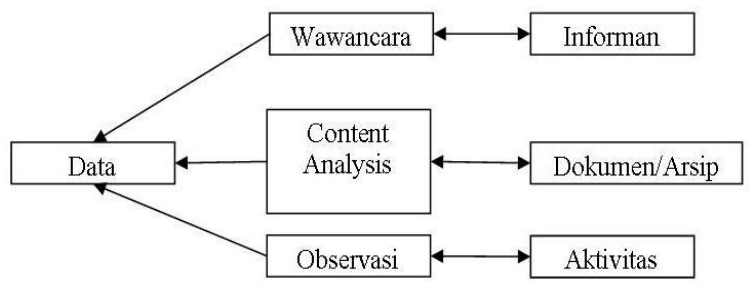

Bagan 3.1: Trianggulasi Sumber (dalam H.B. Sutopo, 2006: 94)

Trianggulasi teknik menggunakan berbagai metode untuk mengecek data kepada sumber yang sama berupa wawancara terhadap informan baik Kepala Desa, Kepala Dusun, kepala paguyuban dan orang Samin. lalu dicek dengan metode observasi dan dokumentasi.

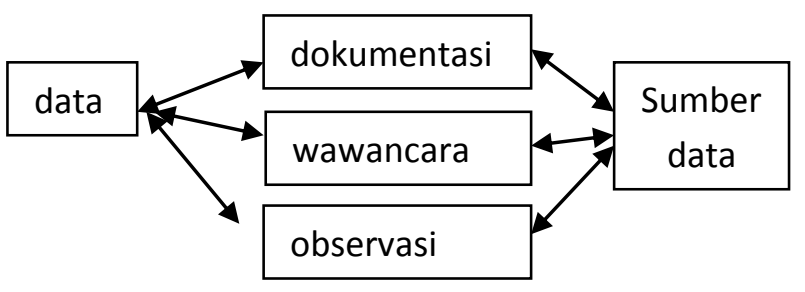

Bagan 3.2: Trianggulasi Teknik (dalam H.B. Sutopo, 2006: 96)

Analisis data yang digunakan adalah analisis data model interaktif Miles dan 
Huberman. Model analisis ini bergerak di antara tiga komponen itu yaitu reduksi data, sajian data, verifikasi data. Adapun secara garis besar proses analisis data dapat dilihat pada bagan di bawah ini:

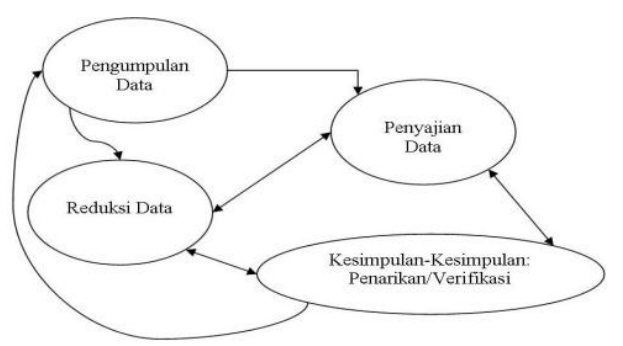

Bagan 3.3. (Analisis Kualitatif Model Interaktif Miles dan Huberman, 2009:20)

\section{Hasil Penelitian}

\section{Sejarah Singkat Asal Usul Masyarakat}

\section{Samin Di desa klopoduwur}

Masyarakat Samin di Desa Klopoduwur lebih suka dikatakan dengan sebutan Wong Sikep. Adanya penyebutan kata Sikep (Siji Kudu Eling Pangeran) yang memiliki arti satu harus ingat Tuhan merupakan sebuah sikap atau kepribadian yang dilakukan, diyakini benar dan membawa ketentraman lahir batin saat itu sampai nanti (Profil Paguyuban Sangkan Paraning Dumadi). Tokoh yang menyebarkan ajaran Samin di Desa Klopoduwur adalah Ki Engkrek (Wawancara Kartono, 25 Februari 2013). Pada saat menyebarkan ajaran Ki Engkrek didampingi oleh tiga pengikut setianya yaitu Samin Surosentiko, Suro Sawur, dan Suro Kuncung. Ki Engkrek mengajarkan lima hal yang dijadikan pedoman hidup bagi masyarakat Samin yaitu pertama, Eling diri pribadi (mengerti atau paham tentang keberadaan diri sendiri sebelum memahami orang lain). Kedua, Ojo mangro tingal (jangan membandingkan atau menduakan Tuhan termasuk ciptaannya. Ketiga, Winengku teteluning atunggal (semua terjadi atas kehendak kuasa dan kebijakan Tuhan. Keempat, Tepati ing janji, lan ojo gampang janji (menepati janji yang diucapkan dan jangan mudah berjanji. Kelima, Welas asih marang sagung dumadi lan sedulur panatagama (kasih sayang kepada segala kehidupan dan saudara pemeluk agama (Wawancara Winarno, 19 April 2013).

Untuk melestarikan kebudayaan masyarakat Samin di Desa Klopoduwur didirikan Paguyuban Sangkan Paraning Dumadi (Awal akhir terjadi) yang memiliki arti segala sesuatu yang ada serta terjadi dimuka bumi berawal dan berakhir karena kehendak kekuasaan dan kebijakan Allah. Tujuan didirikan paguyuban tersebut adalah untuk menunjukan bahwa keberadaan ajaran Sikep bukan ajaran yang bertentangan dengan kehidupan beragama. Di dalam paguyuban tersebut masyarakat Samin membahas beberapa program yang ingin dilaksanakan untuk memperbaiki kehidupan masyarakat Samin agar lebih sejahtera. Program tersebut berupa kelompok tani, dan melakukan pelatihan batik Samin. 


\section{Kehidupan Kaum Perempuan Samin Dari Tahun 1995 Sampai 2012}

Kehidupan perempuan Samin (sedulur Sikep) pada waktu itu masih sangat sederhana, tetapi perempuan Samin tidak merasa kekurangan dalam kehidupannya. Hal ini disebabkan, perempuan Samin memiliki pandangan dalam dirinya ada Tuhan yang telah mencukupi sandang, pangan, panggonan (pakaian, makanan, dan tempat tinggal). Adanya pandangan tersebut membuat perempuan Samin merasa sudah puas dengan kehidupannya saat ini (Wawancara Winarno, 8 April 2013). Dalam kehidupan berumah tangga kaum perempuan Samin merupakan pendamping suami aktif yang selalu patuh akan semua berkataan dari suaminya. Perempuan Samin sangat mandiri, pekerja keras, dan tidak macam-macam dalam kehidupannya. Disisi lain, perempuan Samin menjalani hidupnya dengan apa adanya (Wawancara Suyoto, 25 Februari 2013). Selain itu, perempuan Samin memanfaatkan hasil kekayaan alam disekitarnya untuk memenuhi kebutuhan hidup sehari-hari. Kekayaan alam tersebut berupa kayu bakar yang bisa dijual untuk menambah pemasukan dalam keluarga. Seiring berjalannya waktu kaum perempuan Samin sudah mulai mengalami perubahan semenjak tahun 1995. Perubahan yang terjadi dirasa akibat adanya kemajuan teknologi yang telah mempengaruhi perubahan pada kaum perempuan Samin. Kemajuan teknologi tersebut seperti sudah adanya televise, adanya telepon yang digunakan perempuan Samin untuk berinteraksi dengan masyarakat luar.

\section{Bentuk Perubahan Sosial Kaum Perempuan Samin Tahun 1995-2012}

Bentuk-bentuk perubahan sosial yang dialami kaum perempuan Samin meliputi:

1) Pola perilaku

Kaum perempuan Samin sebelum tahun 1995 mereka sangat tertutup dengan masyarakat sekitar. Hal ini dipengaruhi, oleh adanya diskriminasi dari pemerintah yang menganggap kaum perempuan Samin sebagai sebuah kelompok minoritas yang tidak patuh terhadap peraturan yang telah ditetapkan oleh pemerintah. Peraturan tersebut seperti membayar pajak, dan memiliki kartu tanda penduduk (KTP). Adanya diskriminasi tersebut membuat masyarakat sekitar mengucilkan keberadaan kaum perempuan Samin (Wawancara Winarno, 19 April 2013). Tahun 1995-an pola perilaku kaum perempuan Samin sudah mulai terbuka dengan masyarakat sekitar. Perempuan Samin juga sudah taat dan patuh terhadap setiap peraturan yang ditetapkan oleh pemerintah seperti membayar pajak dan memiliki KTP (Wawancara Sunarso, 6 Mei 2013).

2) Pendidikan Formal

Kaum perempuan samin sebelum tahun 1995 masih banyak yang belum berpendidikan. Hal ini disebabkan, kondisi ekonomi keluarga yang masih serba 
kekurangan dan tidak memiliki banyak biaya untuk bersekolah. Apalagi kebanyakan perempuan Samin saat itu berasal dari keluarga seorang petani yang miskin. Disisi lain, ada anggapan untuk apa perempuan bersekolah tinggi-tinggi pada akhirnya tugas mereka di dapur juga ( Wawancara Sunarso, 6 Mei 2013). Pada tahun 1995 perempuan Samin sudah banyak yang bersekolah. Hal ini dipengaruhi adanya upaya dari pemerintah untuk memperbaikan kehidupan kaum perempuan Samin agar lebih baik lagi. Adanya pendidikan tersebut merubah cara pikir perempuan Samin yang dulunya tidak begitu mementingkan pendidikan justru sekarang sangat peduli akan pendidikan (Wawancara Winarno, 19 April 2013).

3) Pernikahan

Tata cara dalam melaksanakan pernikahan bagi masyarakat Samin (Sikep) yaitu laki-laki memegang tangan dari ayah perempuan kemudian mengucapkan ijab yang berbunyi " Wit kanjeng nabi jejerke lanang demen kukuh janji buk nikah tak lakoni" (Semenjak adanya nabi seorang lakilaki benar- benar cinta terhadap perempuan dan berjanji akan menikahi). Kemudian memegang tangan calon istrinya yang juga mengucapkan " Wit kanjeng nabi demen kukuh janji jejerke wadon buk nikah tak ujudi". Sesudah itu, tokoh Sikep mengucapkan sah sikep rabi sepisan selawase yang memiliki arti sah Sikep nikah satu kali selamanya (Wawancara Winarno,
23 Februari 2013). Dengan mengucapkan ijab tersebut, pernikahan perempuan Samin sudah dianggap sah oleh masyarakat Samin. Pernikahan perempuan Samin pada waktu itu diibaratkan seperti nikah siri yang tidak perlu mencatatkan pernikahan mereka di KUA. Walaupun demikian, perempuan Samin selalu mempertahankan pernikahannya mereka untuk selamanya dan tidak pernah bercerai sampai ajal memisahkan mereka berdua. Bagi perempuan Samin pernikahan hanya dilakukan sekali seumur hidup (Wawancara Suyoto, 25 Februari 2013). Tata cara dalam pernikahan perempuan Samin sudah mengalami perubahan semenjak adanya kebijakan dari pemerintah untuk mencatatkan setiap pernikahan di KUA. Mulai saat itu pernikahan yang dilakukan perempuan Samin dicatatkan di KUA sebagai wujud suatu bentuk ketaatan dalam mematuhi peraturan dari pemerintah.

4) Cara berpakaian

Cara berpakaian kaum perempuan Samin sebelum tahun 1995-an masih menggunakan baju atasan kebaya dan bawahan kain jarik panjangnya di bawah mata kaki yang mencerminkan gaya berpakaian perempuan zaman dahulu (Wawancara Suyoto, 25 Februari 2013). Memasuki tahun 1995 perempuan Samin sudah banyak mengalami perubahan dalam hal gaya berpakaian. Masuknya arus modernisasi mengubah cara pandang kaum perempuan Samin untuk mengikuti 
kemajuan zaman (Wawancara Djasmin, 6 Mei 2013). Hal ini disebabkan apabila kaum perempuan Samin masih tetap mempertahankan gaya berpakaiannya tersebut, tentu mereka akan dianggap perempuan yang ketinggalan zaman dan kuno oleh masyarakat sekitarnya.

\section{Dampak Perubahan Sosial Bagi} Kehidupan Kaum Perempuan Samin

1) Dampak positif

a) Pola Interaksi

Perempuan Samin sebelum mengalami perubahan pola interaksi yang dilakukan cenderung tertutup dengan masyarakat sekitar. Pada saat itu, perempuan Samin hanya melakukan interaksi dengan sesama komunitasnya saja dan hanya terbatas pada ruang lingkup kecil. Hal ini disebabkan, perempuan Samin belum tersentuh oleh adanya perubahan dalam hidupnya (Wawancara Kartono, 25 Februari 2013). Tahun 1995-an perempuan Samin sudah mengalami transisi dalam hal pola interaksi yang cukup luas. Hal ini dipengaruhi oleh adanya sikap keterbukaan perempuan Samin dengan masyarakat sekitar. Kehidupan perempuan Samin yang dulunya sangat tradisional dan cenderung biasa saja sekarang mengalami perubahan menuju kehidupan yang modern. Hal ini dapat terlihat dalam kehidupan kaum perempuan Samin yang sudah bisa memanfaatkan kemajuan teknologi. Misalnya, perempuan Samin sudah menggunakan sepeda motor untuk menunjang kegiatannya sehari-hari. Selain itu, medannya yang terlalu berat sehingga perempuan Samin menggunakan sepedah motor agar lebih mudah melakukan kegiatan mereka (Observasi, 13 April 2013).

b) Bidang Pendidikan

Adanya pendidikan dapat memberikan dampak yang cukup besar bagi kondisi perekonomian kaum perempuan Samin (Wawancara Suyoto, 25 Februari 2013). Pendidikan telah merubah cara pikir perempuan Samin yang dulunya tidak begitu mementingkan pendidikan sekarang sangat mengutamakan pendidikan. Dengan adanya pendidikan dapat memperbaiki kondisi perekonomian kaum perempuan Samin. Kondisi perekonomian yang dulunya hanya seorang petani bahkan buruh tani sekarang bisa menjadi pedagang, wirausaha, peternak, dan perangkat desa (Wawancara, Winarno, 19 April 2013)

c) Bidang Bermasyarakat

Perempuan Samin sudah mengalami perubahan dalam kehidupan bermasyarakat. Hal ini dapat terlihat dalam kehidupan sehari-hari perempuan Samin yang sudah bisa membaur dengan masyarakat sekitar, bahkan saling tolong menolong dan gotong royong dengan warga sekitar (Observasi, 18 April 2013). Adanya sikap tersebut membuat masyarakat tidak lagi mengucilkan keberadaannya bahkan sudah bisa menerima keberadaan mereka dengan baik.

2) Dampak negatif adanya perubahan 
Terjadinya perubahan dalam kaum perempuan Samin memberikan dampak pada hilangnya kepribadian dari sebuah kelompok minoritas (Wawancara Winarno, 19 April 2013). Kepribadian yang dulu sangat memegang teguh adat istiadat dari leluhurnya sekarang sudah mengalami perubahan. Perubahan itu dapat merusak kepribadian dari seseorang yang dulu sangat fanatik dengan ajaran leluhurnya sekarang sudah mulai memudar.

\section{Pembahasan}

\section{A. Bentuk Perubahan Sosial Kaum Perempuan Samin Di Desa} Klopoduwur Kecamatan Banjarejo Kabupaten Blora Tahun 1995-2012

Pada dasarnya, perubahan yang terjadi pada kaum perempuan Samin ini yang kemudian dapat mengacu bahwa peralihan era atau masa pada waktu tertentu juga berdampak pada pendirian dinamis. Pernyataan ini tentu secara sederhana akan terlihat oleh sebuah teori yang dikemukakan Inkels (dalam Syahrial Syarbaini dan Rusdiyanta, 2009: 141) bahwa perubahan tersebut terlingkup dalam tiga hal yakni pertama, Unilinear theory of evolution yang menyatakan bahwa masyarakat dan manusia mengalami perkembangan dengan tahap-tahap tertentu dimulai dari bentuk sederhana sampai kepada bentuk kompleks yang sempurna, Kedua, Universal theory of evolution menyatakan perkembangan masyarakat tidak perlu melalui tahap tertentu yang tetap melainkan berubah dari hasil perkembangan kelompok homogen kepada heterogen, Ketiga, multilined theoritis of evolution yang menekankan pada perubahan yang terjadi karena pengaruh dari berbagai aspek, seperti pengaruh sistem mata pencaharian serta sistem berburu ke bertani. Adapun bentuk perubahan sosial yang ada pada kaum perempuan Samin tersebut, gambaran umumnya akan dapat terlihat jelas sesuai yang diutarakan oleh Syarial Syarbaini dan Rusdiyanta (2009: 138-140) yakni pertama, perubahan secara cepat dan perubahan yang lambat dan kedua, perubahan yang direncanakan dan perubahan yang tidak direncanakan. Berdasarkan konsep dari pemaparan itu Bentuk-bentuknya dapat tersaji lebih rinci sebagai berikut:

1. Perubahan yang secara cepat dan perubahan secara lambat

a) Perubahan secara cepat

Pada dasarnya kaum perempuan Samin dengan adanya kemajuan teknologi ini yang dirasa termasuk dalam mempengaruhi efek yang begitu cepat dalam pola perubahan itu. Hal ini dapat dijelaskan bahwa kemajuan teknologi telah membawa kehidupan kaum perempuan Samin yang sebelumnya masih tergantung pada nuansa tradisional dan apa adanya, serta ada peralihan dengan memanfaatkan teknologi tentu akan memberi dampak bagi 
kehidupan kaum perempuan Samin. Pada kenyataannya, perubahan ini diperkirakan berlangsung sejak tahun 1995-an yang notabene pada masa itu transisi ilmu pengetahuan dan teknologi sedikit lebih maju mampu dimanfaatkan oleh kaum perempuan Samin. Memasuki tahun 2000an pola teknologi yang konsumtif telah merubah semua budaya mereka. mereka dengan menginginkan hidup yang lebih layak dan tentu berpandangan bahwa teknologi itu penting guna memperlancar keseharian mereka. Lebih lanjut, sama dengan masyarakat pada umumnya bahwa mereka juga menggunakan alat komunikasi seperti handphone sehingga pemanfaatan ini akan menunjang dalam berkomunikasi.

b) Perubahan yang bersifat Lambat

Perubahan ini dapat terlihat bagaimana perubahan dari cara berpakaian kaum perempuan Samin. Cara berpakaian kaum perempuan Samin yang dulunya identik dengan karakteristik yang masih sangat tradisional dengan menggunakan baju atasan (kebaya) dan bawahan (kain jarik). Hal ini dilakukan sebab mereka masih memegang tradisi maupun ajaran dari para leluhurnya. Seiring berjalannya waktu tepatnya sekitar tahun 1995 perempuan Samin sudah sedikit mengalami perubahan. Hal ini disebabkan, karena adanya arus modernisasi yang telah mempengaruhi pola berpikir kaum perempuan Samin untuk mengikuti keberlangsungan zaman. Kaum perempuan Samin tidak lagi (jarang) menggunakan pakaian seperti yang disebutkan diatas (kebaya dengan bawahan kain jarik), melainkan sudah bertransformasi memakai pakaian seperti masyarakat biasanya. Adapun dapat dicontohkan bahwa pakaian yang digunakan perempuan Samin sekarang ini misalnya, kaos, kemeja, batik dan sebagainya, sedangkan motif kebaya biasanya hanya dipakai bila ada acara-acara penting saja yang menyangkut pada perhelatan besar kaum Samin meskipun saat ini terlihat cukup jarang. Adanya perubahan tersebut terkadang membuat ketidakadanya perbedaan yang mencolok antara perempuan Samin dengan masyarakat sekitarnya.

2. Perubahan yang direncanakan dan perubahan yang tidak direncanakan

a) Perubahan yang direncanakan

1) Pernikahan

Pernikahan yang dilakukan perempuan Samin pada hakekatnya ketika dahulu hanya menggunakan kepercayaan saja. Dengan adanya konsep ini tentu pernikahannya tidak perlu dicatatkan secara resmi dalam lembaga seperti KUA. Meskipun demikian, pernikahan yang dilakukan perempuan Samin bisa langgeng dan cenderung tidak (jarang) pernah berpisah. Hal ini, muncul karena disebabkan sesuai dengan prinsip kaum perempuan Samin yang seperti umumnya hanya melakukan pernikahan sekali seumur hidup. Tahun 1995-an pernikahan yang dilakukan 
oleh kaum perempuan Samin, kemudian dengan mengikuti pola zaman yang terjadi, maka selanjutnya telah dilegalkan secara sah di KUA. Mereka beranggapan jika pernikahan tidak dicatatkan dalam KUA, maka secara otomatis pernikahan tersebut tidak akan diakui oleh Negara sebagai otoritas penuh. Lebih lanjut, juga memberi dampak pada keturunan perempuan Samin yang nantinya tidak bisa memiliki Akta kelahiran dan otomotis dengan perubahan yang ada di kemudian hari akan sulit untuk mendaftarkan anak-anaknya ke sekolah sebab pernikahan orang tuanya tidak sah di mata hukum.

2) Pendidikan formal

Kaum Perempuan Samin sebelum tahun 1995 antusiasme dalam bidang pendidikan masih sangat kurang atau dapat dikatakan tidak memiliki minat sama sekali, disebabkan mereka pada dasarnya hanya dididik untuk menjadi pegawai rumahan saja itu sudah cukup. Selain itu, pemikiran ini juga disebabkan oleh adanya pandangan dari para kaum perempuan Samin bahwa bila nanti mengenyam sekolah, maka akan membuat mereka pintar dan dapat mempintari bangsanya sendiri. Adanya sikap tersebut dipengaruhi oleh rasa trauma pada kaum perempuan Samin pada masa penjajahan belanda. Pada masa itu, para penjajah melarang keras perempuan Samin untuk bersekolah. Memasuki tahun 1995-an kaum perempuan Samin lama kelamaan mulai menghilangkan rasa trauma itu, dan pada akhirnya mulai beradaptasi dengan dunia pendidikan. Hal ini dibuktikan dengan adanya sekolah yang sengaja dibangun pemerintah untuk keperluan masyarakat Samin (umumnya) dan khususnya kaum perempuan Samin itu sendiri, apalagi semenjak Tahun 2000 mereka telah banyak mendapakan pengalaman di sekolah baik dari tingkat SD sampai SMA.

3) Mematuhi peraturan struktur lembaga Pemerintahan (Desa)

Menginjak dekade tahun 1995 sampai tahun 2000-an dimana masa ini Negara Indonesia sudah dipimpin oleh bangsanya sediri dan sudah barang tentu mereka sedikit telah mulai menaati apa yang diperintahkan oleh lembaga pemerintah desa. Demikian juga dengan kaum perempuan Samin yang mau akan semua kebijakan yang diterapkan pemerintah sebab menurut pandangan mereka kalau untuk bangsanya sendiri mereka mau untuk melakukan hal apapun. Adanya perubahan cara pikir perempuan Samin terhadap sikapnya pada pemerintah, implementasinya mereka mentaati setiap peraturan dari pemerintah. Misalnya, peraturan untuk membayar pajak, memiliki kartu tanda penduduk, pemilu, menimbang anaknya di Posyandu.

b) Perubahan yang tidak direncanakan

Kurun waktu antara tahun 19952012, tepatnya sekitar tahun 1997-an yang mana pada saat itu indonesia mengalami transisi dalam bidang ekonomi yang cukup 
luar biasa yang mengakibatkan adanya krisis moneter. Terjadinya krisis moneter mempengaruhi kehidupan perempuan Samin secara drastis. Kehidupan yang dulunya sangat mengandalkan hasil pertanian sekarang terpaksa harus menjual tanah pertaniannya untuk mencukupi kebutuhan hidup. Meskipun demikian, perempuan Samin tetap bisa bekerja di lahan pertanian tersebut walaupun hanya sebagai buruh tani untuk mencukupi kebutuhan mereka. Selain itu, perempuan Samin juga ada yang beralih profesi menjadi pedagang untuk memperbaiki kondisi perekonomian mereka.

\section{B. Faktor-Faktor Perubahan Sosial Kaum Perempuan Samin Di Desa Klopoduwur Kecamatan Banjarejo Kabupaten Blora Tahun 1995-2012}

1. Faktor dari Dalam (Intern)

Hakekatnya pada kaum perempuan Samin faktor intern yang menjadi penyebab terjadi perubahan itu meliputi: pertama, berupa sebuah sikap dari perempuan Samin yang bersedia membuka diri dan menerima kebudayaan dari luar. Adanya sikap membuka diri tersebut terlihat pada perubahan perilaku perempuan Samin yang sudah bersedia dalam keikutsertaan mengenyam bidang pendidikan. Kedua, masuknya penduduk baru juga akan mempengaruhi pola perubahan. Hal ini diakibatkan karena penduduk baru dengan budayanya yang dibawa dari luar secara tidak langsung akan terbawa pada satu efek penyaluran dengan masyarakat sekitar melalui proses interaksinya sehingga memungkinkan untuk berubah. Misalnya saja terkadang penduduk yang baru di daerahnya hidup dengan pola yang konsumtif, sehingga setelah bergabung dengan masyarakat yang baru khususnya pada kaum perempuan Samin tentu secara tidak langsung akan terkontaminasi dengan apa yang dibawa pada pendatang baru itu. Ketiga, rasa tidak puas pada suatu pola hidup yang lama. Adanya ketidakpuasan ini akibat dari perkembangan ilmu teknologi yang ada dan bagi kaum perempuan Samin terkadang ada rasa kejenuhan dan memiliki keinginan sesuai dengan umumnya pada masyarakatnya sehingga keinginan kuat untuk mencoba merubah pada sesuatu yang baru pada akhirnya akan menjadi sebuah kebiasaan.

\section{Faktor dari Luar (Ekstern)}

Faktor ekstern perubahan sosial kaum perempuan Samin lebih pada ranah budaya dari masyarakat Samin yang mulai berubah seperti yang terjabarkan berikut ini: Pertama, dalam sistem kepercayaan atau religi yang dianut perempuan Samin. Perempuan Samin yang dulunya tidak menganut agama yang ditetapkan oleh pemerintah. Pada saat ini telah mengalami perubahan akibat terpengaruh oleh kebudayaan dari masyarakat sekitar dengan mulai memeluk agama islam. Kedua, dalam mata pencaharian. Perempuan Samin sebelum mengalami perubahan hanya 
memiliki mata pencaharian di bidang pertanian saja dan paling pantang melakukan pekerjaan dalam bidang perdagangan. Seiring berjalannya waktu, anggapan tersebut mulai memudar akibat terdesak kebutuhan hidup yang semakin melonjak, sehingga perempuan Samin mulai mencoba melakukan perdagangan. Di samping itu, perlu juga diketengahkan bahwa munculnya media masa yang menyuguhkan informasi yang inovatif dirasa juga menjadi faktor lain untuk kaum perempuan Samin dalam perubahannya. adanya media massa tentu akan pula mengubah pola berpikir samin untuk menjadi lebih modernitas, sebab dari hal ini juga mereka akan mencoba mengeksplorasi berbagai temuan informasi itu dalam mempermudah kehidupannya.

\section{Dampak Perubahan Sosial Bagi Kehidupan Kaum Perempuan Samin Tahun 1995-2012}

\section{Ekonomi}

Kehidupan kaum perempuan Samin sebelum mengalami perubahan masih sangat sederhana dengan bercirikan pada ketradisionalan. Meskipun kehidupan kaum perempuan Samin sederhana, akan tetapi pada substansinya mereka tidak merasa kekurangan. Keadaan tersebut mulai berangsur berubah ketika pada saat segala kebutuhan hidup serba mahal. mereka merasa kesulitan dalam memperoleh mata uang, sehingga mereka melakukan pekerjaan secara serabutan maupun buruh.
Seiring berjalannya waktu, perekonomian perempuan Samin mulai membaik. Hal ini diakibatkan berbagai macam bantuan yang diberikan oleh pemerintah. Bantuan tersebut berupa pemberian hewan ternak misalnya sapi, kambing yang dikemudian dari pemanfaatannya dijadikan modal untuk memperbaiki kondisi kehidupannya.

2. Pola Interaksi

Adanya proses interaksi ini memberikan dampak yang cukup besar bagi perubahan kaum perempuan samin. Perubahan tersebut seperti pada gaya hidup kaum perempuan Samin. Perempuan Samin sudah mampu berinteraksi bahkan bekerja sama dengan masyarakat sekitar seperti kerja bakti dan gotong royong. Maka dari itu, dengan adanya perubahan itu masyarakat sekitar sudah bisa menerima keberadaan perempuan samin dan tidak lagi mengabaikan keberadaan mereka sehingga terjalin komunikasi yang intensif dan positif.

3. Persamaan kedudukan

Terjadinya perubahan dalam diri kaum perempuan Samin bertujuan untuk menyamakan kedudukan perempuan Samin dengan masyarakat sekitar. Pernyataan tersebut disebabkan bahwa kedudukan perempuan Samin yang dulunya itu sering direndahkan oleh masyarakat sekitar. Hal ini dipengaruhi oleh anggapan dari masyarakat terhadap perempuan Samin yang kurang berpendidikan. Semua anggapan tersebut hilang pada saat perempuan Samin sudah bisa menyamakan 
kedudukan mereka akibat sudah tersentuh ranah pendidikan.

Berdasarkan pemaparan tersebut maka secara gambaran umum, Adanya perubahan yang terjadi dalam diri kaum perempuan Samin memberikan dampak tersendiri dalam kehidupan kaum perempuan Samin antara tahun 1995 sampai 2012. Adanya arus globalisasi merubah paradigma perempuan Samin menuju ke arah modernisasi. Modernisasi telah merubah kehidupan perempuan Samin menuju pembaharuan dari berbagai aspek. Aspek tersebut meliputi adanya kemajuan teknologi yang telah dimanfaatkan oleh perempuan Samin misalnya penggunaan sepeda motor, handphone, televisi, dan alat pertanian yang serba canggih. perubahan sosial kaum perempuan Samin juga terjadi dalam bidang ekonomi. Ekonomi perempuan Samin yang dulunya serba kekurangan atau tidak bisa mencukupi kehidupan keseharian sekarang berusaha untuk memperbaiki kondisi tersebut. Cara yang dilakukan perempuan Samin dengan melakukan perubahan dalam sistem mata pencaharian yang bervariasi bisa menopang kehidupan kaum perempuan. Adanya perubahan dalam diri perempuan Samin juga dapat menyamakan kedudukan perempuan Samin dengan masyarakat sekitar, sehingga tidak ada perbedaan antara perempuan Samin dengan masyarakat sekitar.

\section{Simpulan dan Saran}

\section{A. Simpulan}

bentuk perubahan sosial yang terjadi pada kaum perempuan Samin berupa perubahan secara cepat menyangkut pemanfaatan teknologi yang memberi efek pada perempuan Samin, dan perubahan lambat berupa pola perilaku mereka yang membutuhkan penyesuaian lebih lama seperti peralihan cara berpakaian dari kebaya ke pakaian modern. Bentuk perubahan yang direncanakan seperti pernikahan yang bersedia mencatatkan ke KUA, dalam hal pendidikan ada kemauan bersekolah serta ada kesediaan patuh terhadap pemerintah. Perubahan tidak direncanakan yakni mereka tidak memiliki lahan pertanian (akibat ketidaksadaran) dalam persoalan ekonomi sekitar tahun 1997. Faktor yang berpengaruh dalam perubahan itu ada dua yakni intern meliputi keterbukaan dengan masyarakat luar, adanya penduduk baru, dan adanya ketidakpuasan pada pola hidup yang lama.

Faktor ekstern meliputi mata pencaharian di bidang pertanian, sistem kepercayaan serta media masa sehingga ada penambahan informasi baru. Dampak yang dialami oleh kaum perempuan Samin akibat dari perubahan dapat terwujud dalam beberapa hal antara lain 1). Kehidupan kaum perempuan Samin yang dulunya sangat tradisional sekarang mulai mengalami kemajuan akibat arus globalisasi berupa kemajuan teknologi yang telah 
memasuki keseharian mereka. 2). Ekonomi perempuan Samin yang dulunya kekurangan sekarang berusaha untuk memperbaiki kondisi tersebut, 3). Adanya perubahan dalam perempuan Samin juga dapat menyamakan kedudukan perempuan Samin dengan masyarakat sekitar, sehingga tidak ada perbedaan antara perempuan Samin dengan masyarakat sekitar.

\section{B. Saran}

\section{Bagi Pemerintah Kabupaten Blora}

Diharapkan pemerintah daerah mampu memberi perhatian penuh terhadap pemberdayaan kaum perempuan dalam keberlangsungan hidupnya. Perhatian tersebut dapat diberikan melalui programprogram pemerintah yang mengarah pada pemberdayaan Sumber Daya Manusia baik secara materiil maupun non materiil, sehingga kesejahteraan umumnya masyarakat Samin akan terpenuhi.

\section{Bagi Dinas Pariwisata dan Kebudayaan}

Diharapkan dinas yang terkait juga memberi perhatian sepenuhnya bagi masyarakat Samin khususnya kaum perempuannya, sebab Samin menjadi kebanggaan tersendiri karena merupakan salah satu bentuk dari kearifan lokal di wilayah Kabupaten Blora yang perlu ada pelestariannya. Di samping itu, diharapkan pula bagi dinas pariwisata untuk mengembangkan keunikan budaya tersendiri yang ada di masyarakat Samin dan juga perlu ada tindakan untuk terus dipromosikan maupun diperkenalkan ke masyarakat luas, sehingga nantinya akan menjadi sebuah icon pariwisata khususnya di daerah Blora dan sekitarnya.

\section{Daftar Pustaka}

Abdulsyani. 2012. Sosiologi: Skematika, Teori, dan Terapan. Jakarta: PT Bumi Aksara.

Abraham Nurcahyo dan Yudi Hartono. 2008. Pengantar Antropologi. Magetan: Lembaga Edukasi Swastika.

Andi Prastowo. Metode. 2012 Penelitian Kualitatif Dalam Perspektif Rancangan Penelitian. Yogyakarta: AR RUZZ MEDIA.

Andrik Purwasito. 2003. Agama Tradisional: Potret Kearifan Hidup Masyarakat Samin dan Tengger. Yogyakarta: Lkis.

Ary, Donald, Dan A. Razavieh. Tanpa Tahun. Pengantar Penelitian Dalam Pendidikan. Terjemahan oleh Arief Furchan. 2011. Yogyakarta: Pustaka Belajar.

Burhan Bungin. 2009. Sosiologi Komunikasi: Teori, Paradigma, dan Diskursus Teknologi Komunikasi di Masyarakat. Jakarta: Kencana.

Dadang Supardan. 2008. Pengantar Ilmu Sosial Sebuah Kajian Pendekatan Struktural. Jakarta: Bumi Aksara.

Dany Haryanto dan Edwi Nugroho. 2011. Pengantar Sosiologi Dasar. Jakarta: PT. Prestasi Pustakaraya.

Dewi Wulansari. 2009. Sosiologi: Konsep Dan Teori. Bandung: PT. Refika Aditama. 
Dja`Man Satori dan Aan Komariah. 2011. Metodologi Penelitian Kualitatif. Bandung: Alfabeta.

Djunaidi Ghony dan Fauzan Almansur. 2012. Metodologi Penelitian Kualitatif. Yogjakarta: AR RUZZ MEDIA.

Dwi Narwoko dan Bagong Suyanto. 2010. Sosiologi: Teks Pengantar dan Terapan. Jakarta: Kencana.

Emzir. 2011. Metodologi Penelitian Kualitatif: Analisis Data. Jakarta: Rajawali Pers.

Eti Nurhayati. 2012. Psikologi Perempuan: Dalam Berbagai Perspektif. Yogjakarta: Pustaka Belajar.

Fauzie Ridjal dkk. 1993. Dinamika Gerakan Perempuan di Indonesia. Yogyakarta: PT Tiara Wacana Jogja.

Hardjito Notopuro. 1993. Peranan Wanita Dalam Masa Pembangunan di Indonesia. Jakarta: Ghalia Indonesia.

Haris Herdiansyah.2011. Metode Penelitian Kualitatif untuk ilmu-ilmu sosial. Jakarta: Salemba Humanika.

Husain Haikal. 2012. Wanita Dalam Pembinaan Karakter Bangsa. Yogyakarta: Universitas Negeri Jogjakarta dan Pustaka Belajar.

Irwan Abdullah. 2001. Seks, Gender, dan Reproduksi Kekuasaan. Yogyakarta: Tarawang Press.

Irwan Abdullah. 2003. Sangkan parang Gender. Yogyakarta: Pustaka Pelajar.

Jacobus Ranjabar. 2008. Perubahan Sosial Dalam Teori Makro Pendekatan Realitas Sosial. Bandung: Alfabeta.

Jajat Burhanudin dan Oman Fathurahman. 2004. Tentang Perempuan Islam: Wacana Dan Gerakan. Jakarta: PT. Gramedia Pustaka Utama.
Judi Wacjman. 1991. Feminisme Versus Teknologi. Terjemahan oleh Ima Susilowati. 2001. Jogjakarta: SBPY (Sekretariat Bersama Perempuan Jogjakarta).

Lexy J. Moleong.2012. Metodologi Penelitian Kualitatif. Bandung: PT Remaja Rosdakarya.

Mahatma Gandhi. 1970. Kaum Perempuan dan Ketidakadilan Sosial. Terjemahan oleh Siti Farida. 2002. Yogjakarta: Pustaka Belajar.

Mansour Fakih. 2007. Analisis Gender dan Transformasi Sosial. Jogyakarta: Pustaka Belajar.

Masri Singarimbun. 1996. Penduduk Dan Perubahan . Yogyakarta: pustaka belajar.

Miles dan Huberman. 1992. Analisis Data Kualitatif. Terjemahan oleh Tjetjep Rohendi Rohidi. 2009. Jakarta : Universitas Indonesia

Muhammad Teguh. 1999. Metodologi Penelitian Ekonomi Teori dan Aplikasi. Jakarta: PT. Rajagrafindo Persada.

Nanang Martono. 2012. Sosiologi Perubahan Sosial. Jakarta: PT Raja Grafindo Persada.

Nancy Van Vuuren. 1983. Wanita dan Karier: Bagaimana Mengenal dan Mengatur Karya. Terjemahan Oleh Lunandi. 1990.Yogyakarta: Kanisius.

Nursyahbani Katjasungkana. 2001. Potret Perempuan: Tinjauan Politik, Ekonomi, Hukum Di Zaman Orde Baru. Yogyakarta: Pusat Studi Wanita dan Pustaka Belajar.

Saifuddin Azwar. 2004. Metode Penelitian. Yogyakarta: Pustaka Belajar. 
Soerjono Soekanto. 2010. Sosiologi Suatu Pengantar. Jakarta: Raja Grafindo Persada.

Sugiono. 2012. Memahami Penelitian Kualitatif. Bandung: Alfabeta.

Suharsimi Arikunto. 2010. Prosedur Penelitian. Jakarta: Rineka Cipta.

Sutopo, H.B. 2006. Metodologi Penelitian Kualitatif. Surakarta. Universitas Sebelas Maret.

Syahrial Syarbaini dan Rusdiyanta. 2009. Dasar-Dasar Sosiologi. Jogyakarta: Graha ilmu.

Sztompka, Piotr. 2008. Sosiologi Perubahan Sosial. Jakarta: Prenada.

Tineke Hellwig. 2007. Citra Kaum Perempuan Di Hindia Belanda. Terjemahan oleh Mien Joebhaar. 2007. Jakarta: Obor.

Titi Mumfangati. 2007. Kearifan Lokal di Lingkungan Masyarakat Samin Kabupaten Blora Jawa Tengah: Kantor Pariwisata dan Kebudayaan Blora.

Uhar Suharsaputra. 2012. Metode Penelitian: Kuantitatif, Kualitatif, dan Tindakan. Bandung: PT Refika Aditama.

Ulber Silalahi. 2010. Metode Penelitian Sosial. Bandung: PT Refika Aditama 